DE9 1006543

\title{
LABORATORY TESTING OF THE SONNENSCHEIN CHARGER \\ Part Number DTL 12040
}

\author{
J. E. Hardin \\ M. E. Martin
}

September 1990

EG\&G Idaho, Inc.

Idaho Falls, Idaho 83415

Prepared for the

U.S. Department of Energy

Idaho Operations office

Under DOE Contract No. DE-AC07-76ID01570

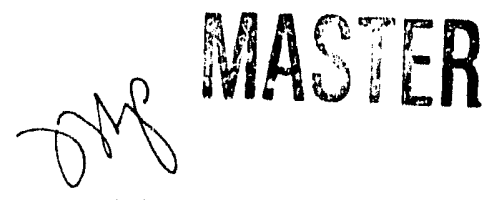

DISIFIBUTIO: - - " ROCUMENT IS UNLIMITED 


\section{CONTENTS}

Page

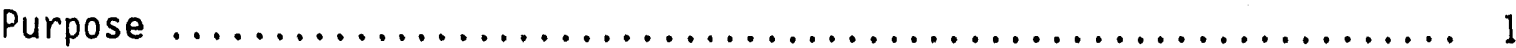

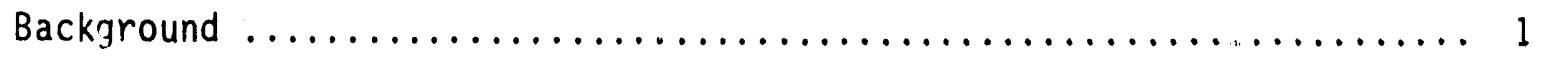

References $\ldots \ldots \ldots \ldots \ldots \ldots \ldots \ldots \ldots \ldots \ldots \ldots \ldots \ldots \ldots \ldots \ldots$

Description of the Charger.............................

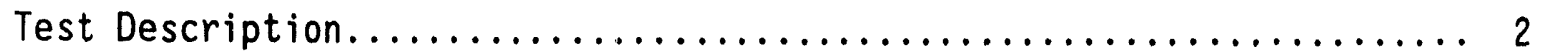



Conclusions and Recommendations $\ldots \ldots \ldots \ldots \ldots \ldots \ldots \ldots \ldots \ldots \ldots \ldots \ldots \ldots \ldots \ldots \ldots$

TABLES

Table 1. Summary of charger tests $\ldots \ldots \ldots \ldots \ldots \ldots \ldots \ldots \ldots \ldots$

Table $2 \ldots$ Summary data shesi for SONNENSCHEIN Battery Pack $54 \ldots \ldots .11$

\section{FIGURES}

Figure 1. Battery charger Front view $\ldots \ldots \ldots \ldots \ldots \ldots \ldots \ldots \ldots$

Figure 2. Battery charger Inside view $\ldots \ldots \ldots \ldots \ldots \ldots \ldots \ldots . \ldots$

Figure 3. Charger Behavior for Tests $1,3,6,7$ and $8 \ldots \ldots \ldots \ldots$

Figure 4. Charger Behavior for Tests 4,5 and $9 \ldots \ldots \ldots \ldots \ldots$

Figure 5. Voltage and Current vs Time for Tests $2,8 \mathrm{~B}$ and $10 \ldots \ldots 10$ 


\section{LABORATORY TESTING OF THE SONNENSCHEIN CHARGER}

\section{Purpose}

This report describes the results of testing the Sonnenschein DTL 12040 battery charger in the INEL battery laboratory. The purpose of this testing was to evaluate the suitability of this charger for charging electric vehicle battery packs made up of Sonnenschein sealed lead acid batteries or possibly other similar batteries. This evaluation consists primarily of identifying the charge algorithm used and evaluating the resulting charge behavior. Other characteristics of the charger that could be significant are al so noted.

\section{Background}

Several participants in the DOE Site Operator program are using or planning to use Sonnenschein sealed lead acid batteries in electric vehicles, such as the DV-6V160 modules currently offered for sale through importation from Germany. Sonnenschein supplies a line of battery chargers for lower voltage applications using these batteries, and they agreed to build a higher voltage charger for INEL evaluation. This charger was purchased for the charging of a battery pack made up of 20 Sonnenschein DV-6V160 type modules. Its purchase cost was $\$ 2,500.00$ not including shipping.

\section{References}

- Sonnenschein charger manual

- INEL Battery Test Procedure ETV-BAT-984 Battery Characterization Test for Battery Modules and Packs

\section{Description of the Charger}

See Figure 1 for a photograph of front of the charger; Figure 2 
shows a view of the inside. The charger has no switches, disconnects or other user-operable controls. The front cabinet door has a key lock.

The charger is of German design and uses European parts for such items as fuses, relays, meters and electronics. Some of these components are not standard in the United States. The manual is also written in German and no attempt was made at this time to translate the manual.

The charger is not provided with a temperature sensor, so the charge behavior is not compensated for battery temperature.

The charge algorithm (confirmed by Sonnenschein Batteries in Germany after this testing) is a I-U-Ia type, meaning that it has a constant current bulk charge, constant voltage stage, and then a constant current trickle charge for cell equalization. The constant current trickle charge is timed and is nominally either 1 hour or 4 hours long depending on the time spent in the I-U portion of the algorithm.

When the charger shuts off at the completion of a charge cycle, it does not go through a subsequent "wake up" and boost cycle as long as it is left connected to the battery. However, disconnecting and reconnecting the battery will result in a boost charge as observed in some tests whether or not any charge has been removed from the battery.

\section{Test Description}

Ten charger tests (i.e. charge cycles) were performed using two batteries at various depths of discharge to identify the type of charge algorithm used. The results of these tests are summarized in Table 1. The first 9 charge cycles were performed using the Sonnensche in DV-6V160 6 volt sealed lead acid battery modules for 
which the charger was designed. The tenth test was done using 10 Johnson Controls 12 volt gel/cell modules, type GC-12V100.

Tests 1 through 7 were done with a battery pack of 20 modules (the design target for the charger). The test daia from charge cycle 2 was lost due to a power outage and a top-off charge $2 B$ was subsequently performed. Data from tests $2 B, 8 B$ arid 10 (top-off charges) were used to look at the behavior of the charger when used to charge an already fully charged battery. Tests 8 and 9 were done using only 19 modules; one module was removed from the pack to look at the effects of a failed module.

For all tests, the charger was powered from 220 volt single phase 60 $\mathrm{Hz}$ power through an isolation transformer. AC input energy (watt-hours) was monitored and compared to the $D C$ energy (watt hours) output to the battery.

Test data was acquired using a NEFF470 data system. Data was recorded at a 5 minute scan interval for all tests except tests $2 B$ and $8 \mathrm{~B}$ which used a 1 minute scan rate. Each scan recorded time, battery voltage, charge current, module voltages, battery temperature and ambient temperature. All tests were performed at a rnom temperature of $23 \pm 2^{\circ} \mathrm{C}$.

\section{Test Results}

Overall charger efficiency was found to be $82.8 \%$ for the tests conducted. Other general test results are summarized in Table 1 following, and more detailed test results are listed in Table 2. Note that the percent overcharge (charge return factor) varied from 5 to $20 \%$ as a consequence of the final charge step, discussed in more detail later. 


\section{Table 1}

Summary of Charger Tests

Test Percent Number Time Time at Time at Ending Amp

Number DOD Modules Clamp Clamp 2.35A Voltage Hours

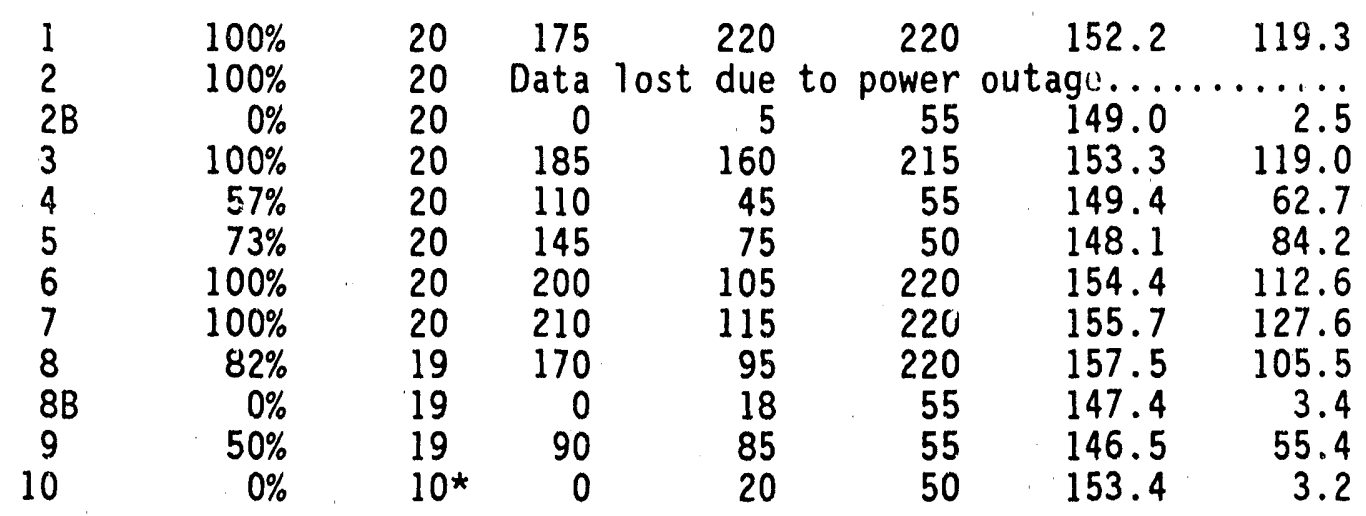

* Johnson Controls $12 \mathrm{~V} \mathrm{gel/cell} \mathrm{modules.} \mathrm{All} \mathrm{other} \mathrm{tests} \mathrm{are}$ Sonnenschein DV-6V160 6V sealed modules.

It can be seen from the data plots (Figures 3,4 and 5) that the basic charge algorithm exhiloited by the charger is a 3-step I-E-Ia algorithm as follows:

- Step $i$ is a constant current $\left(C_{1}\right)$ of 28.35 amps to a $c 7$ amp voltage of 141.5 volts (equal to 2.358 volts/cell).

- Step 2 is a constant voltage (CV) at the clamp voltage of 141.5 volts while tapering current down to 2.35 amps.

- Step 3 is a timed constant current $\left(\mathrm{CI}_{2}\right)$ of 2.35 amps for a time period of either 1 or 4 hours (approximately) depending on the depth of discharge (DOD) of the battery.

The charger has no knowledge of the previous discharge; hence the length of Step 3 is actually determined by the time spent in the I-E portion of the charge (i.e. Steps 1 and 2). If I-E charge time is small (less than 4 huurs according to Sonnenschein), then $\mathrm{CI}_{2}$ time is about 1 hour. If I-E charge time is large, $\mathrm{CI}_{2}$ time is about 4 hours. For the battery used in these tests, Table l shows that 
charge cycles after a discharge to $80 \%$ or greater depth of discharge remain in the $\mathrm{CI}_{2}$ charge step for the longer period while those after a less than $80 \%$ DOD discharge are the shorter duration.

For tests $1,3,6,7$ and 8 , the battery was discharged to greater than $80 \%$ DOD before charge; the battery current and voltage behavior for these tests is shown in Figure 3. The time to reach the clamp voltage for these tests varied from 170 to 210 minutes. The time for which the clamp voltage was held ranged from 95 to 220 minutes, and the time at 2.35 amps $\left(\mathrm{CI}_{2}\right)$ was 220 minutes.

In tests 4, 5 and 9, the battery was discharged less than 80\% DOD; current and voltage behavior for these tests is shown in Figure 4 . The time to reach clamp voltage for these tests varied from 90 to 145 minutes, while the time at clamp voltage ranged from 45 to 85 minutes. The time at 2.35 amps was 55 minutes.

Tests $2 \mathrm{~B}, 8 \mathrm{~B}$ and 10 were top-off charges where the battery had been previously charged and not discharged; see Figure 5 for the current and voltage data. For these tests, the battery reached the clamp voltage immediately, and the constant voltage/taper current portion of the cycle lasted only 6 to 20 minutes. The time at 2.35 amps was still 55 minutes.

\section{Conclusions and Recommendations}

The charger is of European design and uses European parts, some of which are not standard and may not be available in the United States; this obviously creates concerns for maintenance. The manual is also written in German and would require translation to be useful. The cost of this charger was quite high; however, it is not a standard production item, and thus it does not have an established purchase price. Note that the absence of a disconnect or on-off switch would generally require a local power disconnect to be provided externaily 
for emergency use. It is not known whether this design approach wolild violate other U.S. electrical safety codes.

Another significant concern with the charger is its I-E-I charging characteristics, which we do not consider suitable for charging sealed batteries. Other manufacturers recommend I-E charging due to drying out and grid oxidation. However, Sonnenschein has reported that Peugeot France is using I-U-I (I-E-I) charging for their 6V160 batteries in Peugeot electric vehicles very successfully. No data has been made available to evaluate this claim. it can be seen from Table 1 and Figures $1-i$ that the final current step allows the end of charge voltage to exceed the gassing voltage of 2.39 volts/cell for every test; the voltage is generally elevated into this region for most of the $\mathrm{CI}_{2}$ charge step. An I-E type charger is considered to be more suitable for charging these and other sealed lead acid batteries for traction applications.

Additionally, the behavior of the charger is not affected to any significant extent by the condition of the battery, including its temperature or even the complete removai of a battery module. Note that the fully charged JCI battery used for test 10 suffers a significantly higher voltage rise in the final charge step due to the smaller cell size (and hence higher current density) in the 12 volt modules.

It is not recommended that additional chargers of this design be purchased for Site Operator use witi sealed lead acid batteries because of the cost and service concerns as well as the I-E-I charging algorithm. 


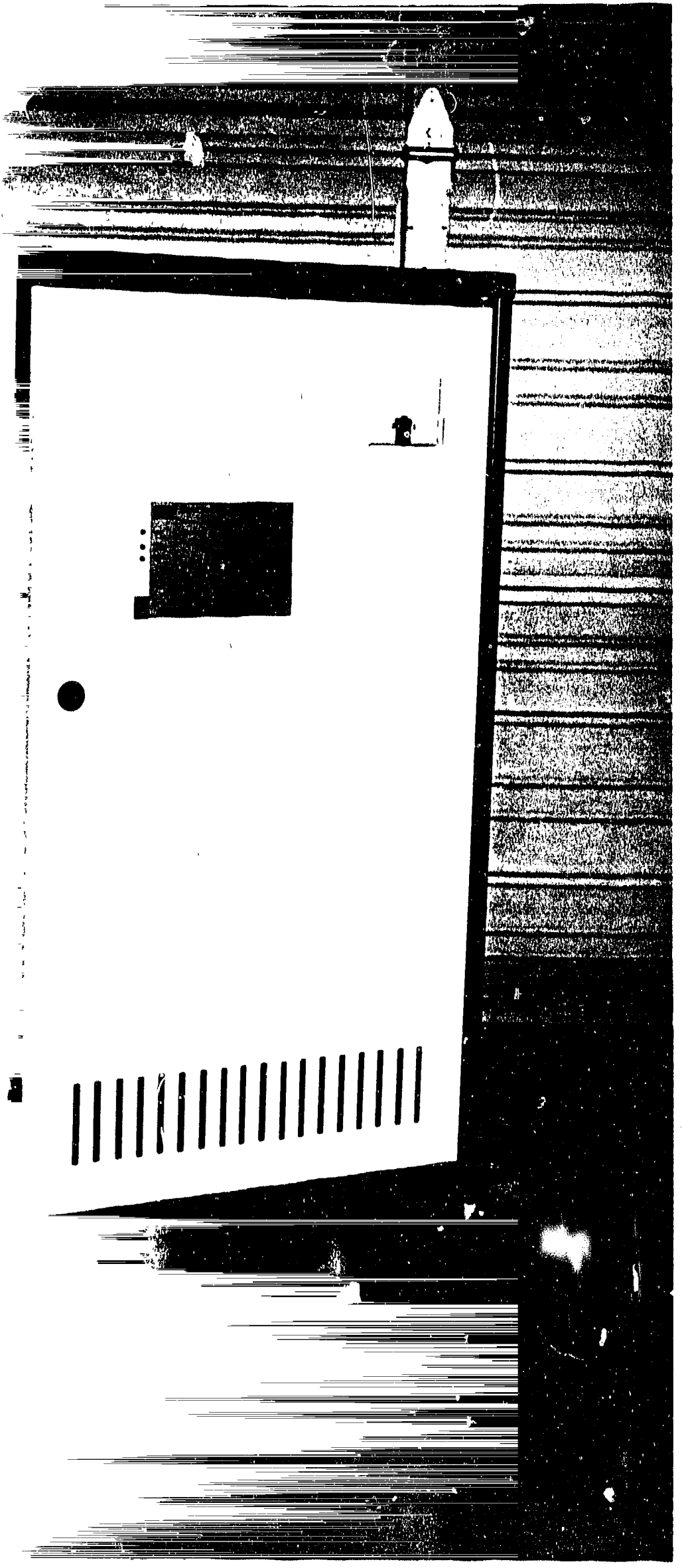

- front view 


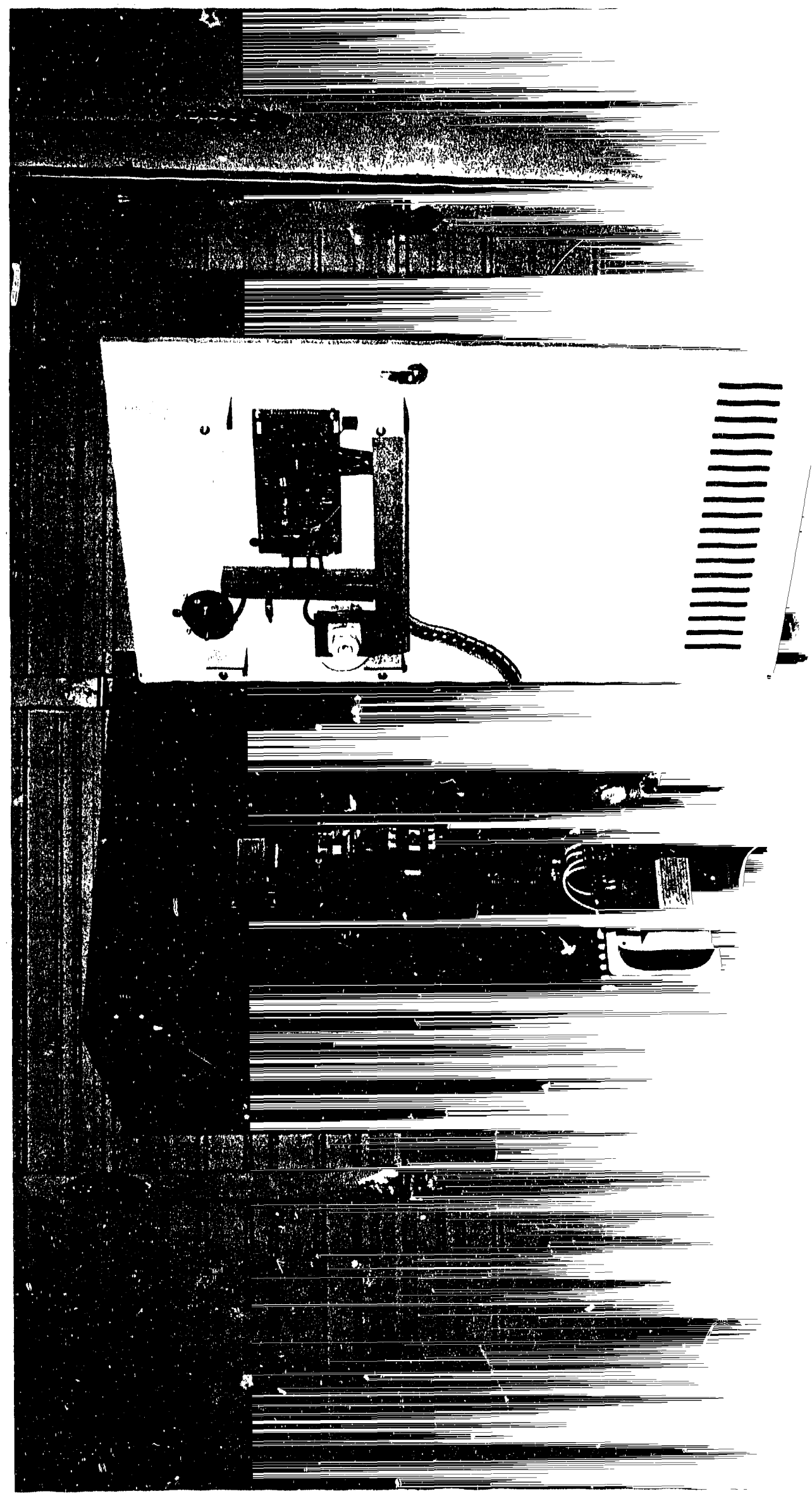

Figure 2. Battery charger - inside view 
SONNENSCHEIN CHARGER TESTS

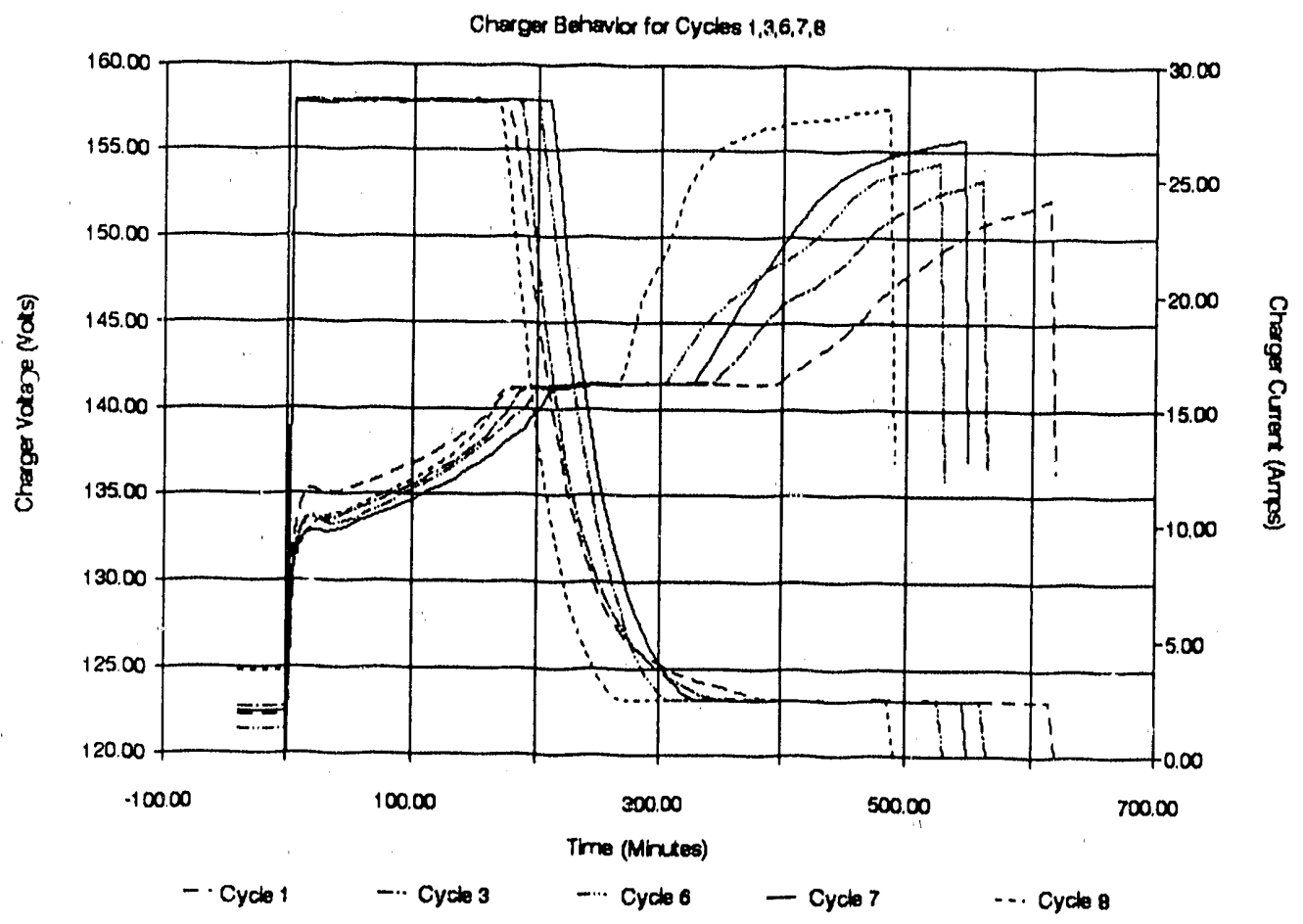

Figure 3.

\section{SONNENSCHEIN CHARGER TESTS}



Figure 4. 


\section{SONNENSCHEIN CHARGER}

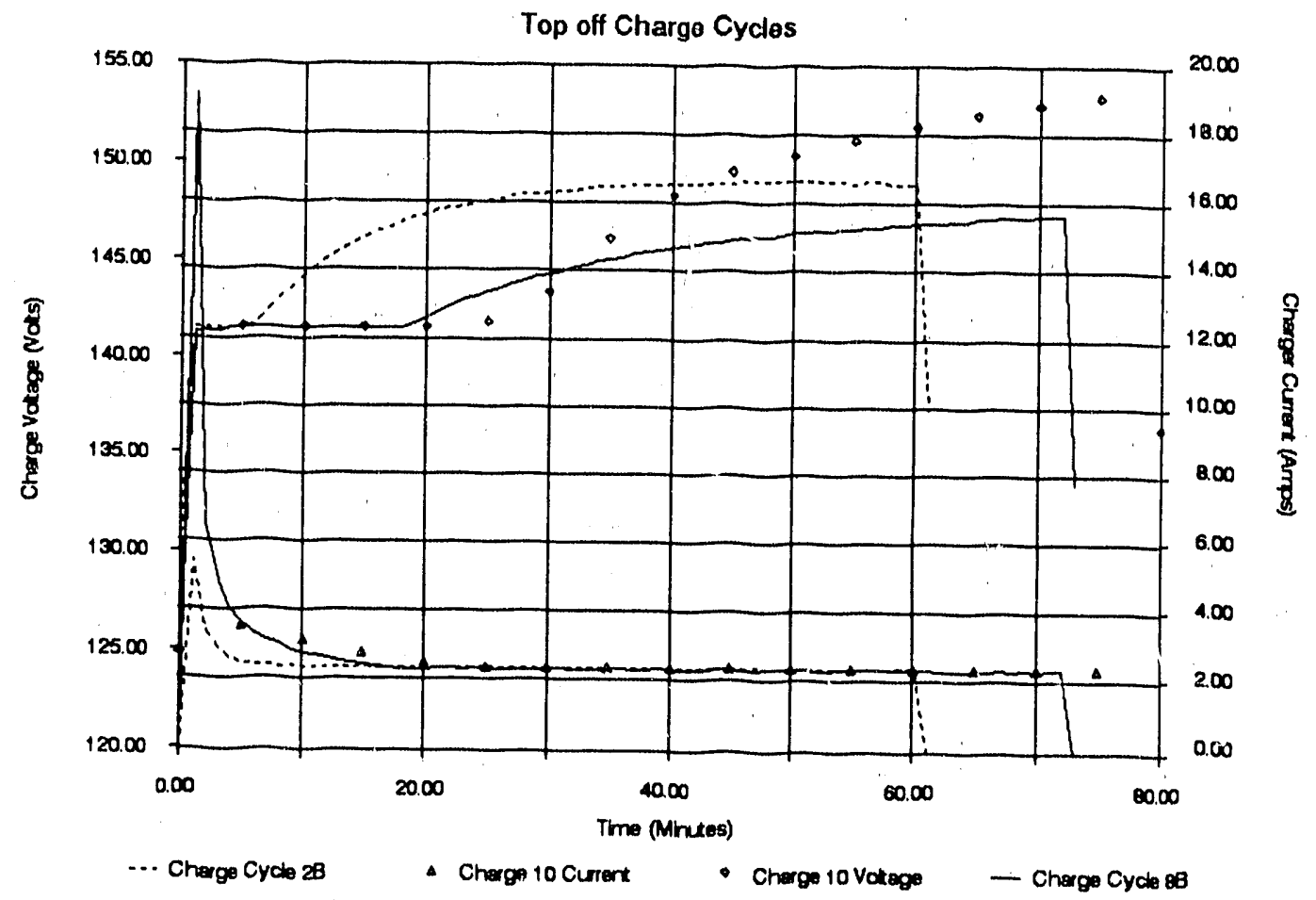

Figure 5. 


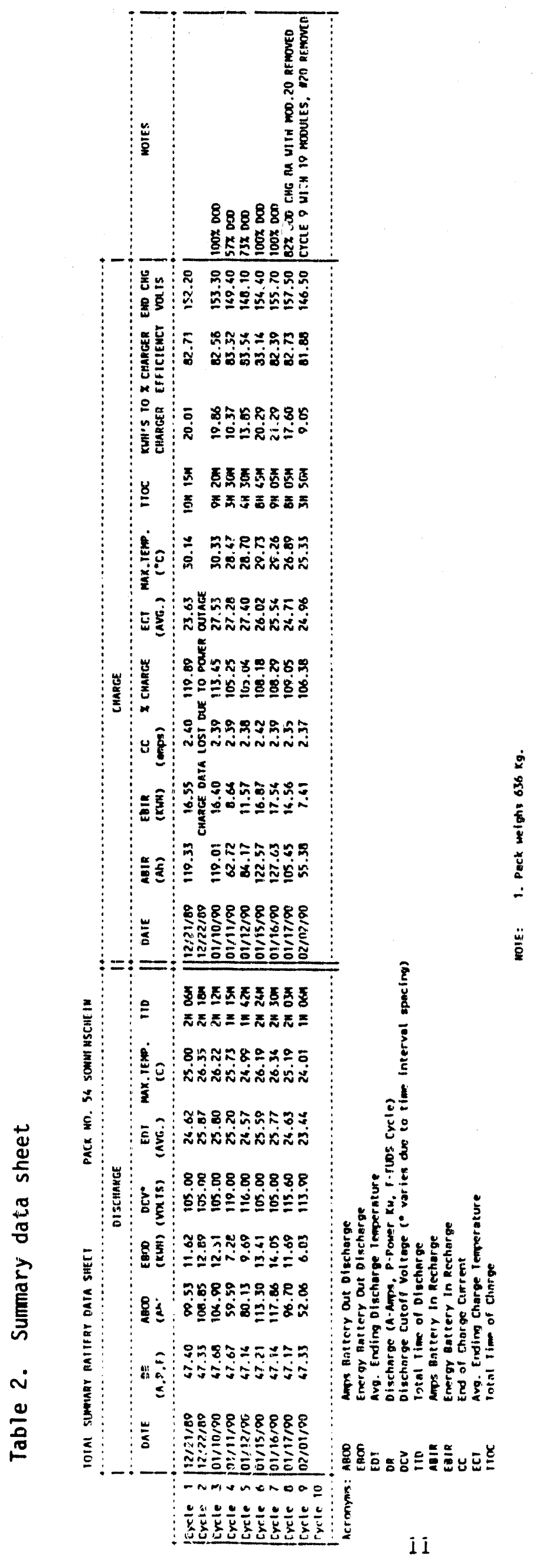



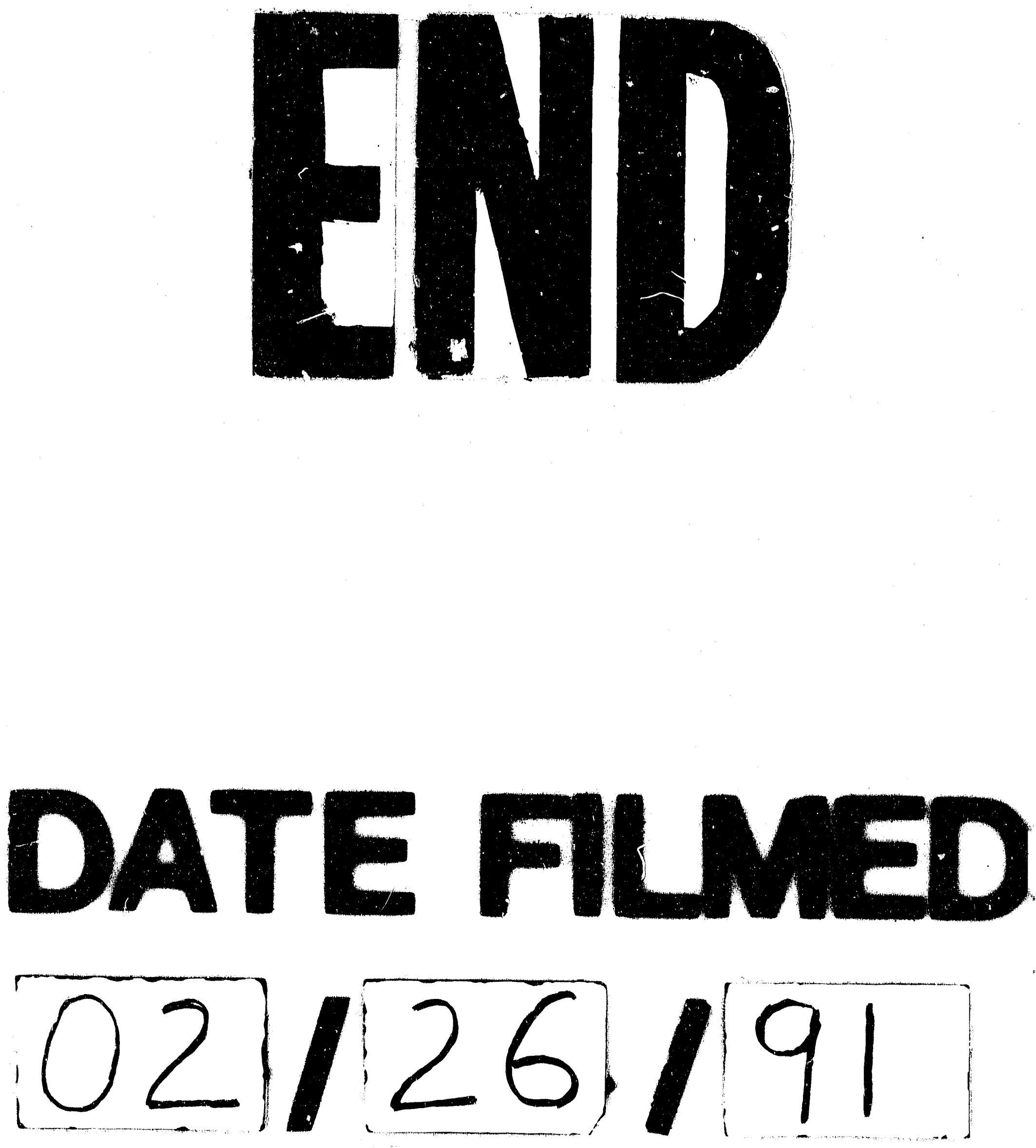
